\title{
The Predicament and Breakthrough of Ideological and Political Education in Colleges and Universities*
}

\author{
Zhiyuan Xu \\ School of Marxism \\ Wuhan University of Technology \\ Wuhan, China 430000
}

\author{
Huiling Fan \\ School of Marxism \\ Wuhan University of Technology \\ Wuhan, China 430000 \\ Yulin Normal University \\ Yulin, China
}

\begin{abstract}
Currently the ideological and political education in colleges and universities in China is facing the disadvantages of outdated concepts, unclear objects relations and lack of system guarantee. To solve these problems, it is necessary to conduct the concept innovation of ideological and political education, including three aspects: adhering to the cultivation standard of "top-notch innovative talents" and being problemoriented, under the theoretical guidance of socialist core values; adhering to the innovation of object relationship, which is to promote the subject consciousness of objects, make the principle of participation clear and calling for the equal dialogue between teachers and students; adhering to the institutional innovation which means strong leadership system, standardized work system and effective incentive mechanism.
\end{abstract}

Keywords—university ideological and political education; concept; object relationship; system

\section{INTRODUCTION}

The report of the 17th national congress of the communist party of China clearly put forward the education policy of "education first, moral education ahead". Under the promotion of the times, this policy has been constantly condensed into the educational concept of "school education takes the education of people as the essence; among the cultivation of morality, intelligence, physique and aesthetics, moral cultivation comes first". Ideological and political education taking moral education as the main body and premise represents the key issue of "what kind of people to cultivate" and "how to cultivate people". That is, to be fully aware of the rules in moral education while putting moral education at a paramount position. "The cultivation of ideological and political quality is the key to the cultivation of talents' character, providing innovative talents with firm spiritual pursuit, strong sense of responsibility and noble code of conduct... "[1]. It is not only the need of the times and society to train builders and successors of socialist cause with excellent moral character, strong innovation ability and outstanding comprehensive quality, but also a strong realistic basis and prerequisite guarantee for practicing socialist core

*This paper is the phased achievement of Guangxi higher education un dergraduate teaching reform project in 2014, "research on education innova tion of ideological and political institutions in universities under the topnotch innovative talent training mode" (2014JGA453) values and realizing the "Chinese dream".

\section{THE PREDICAMENT OF CURRENT IDEOLOGICAL AND} POLITICAL EDUCATION IN COLLEGES AND UNIVERSITIES

Universities and colleges are the main front of education. However, there are a lot of disadvantages in the ideological and political education in Chinese universities and colleges. Specifically, it is mainly reflected as follows: outdated concepts, unclear object relationship and lack of institutional guarantee.

\section{A. Outdated Concepts}

With outdated concepts, the current ideological and political education in universities and colleges lacks multidimensional thinking on the complexity of the society. As its theoretical paradigm is immersed in the "ivory tower", the theory is too delicate and lacks realistic pertinence and impact strength. The main idea of ideological and politica education in some universities even deviates from the original intention of education and falls into the chaos of values.

The ideological and political education must represent epochal character and reflect the educational concept and method of the new era. In China, the purpose of the construction of spiritual civilization has long made it clear that "every kind of ideology and morality that is conducive to the liberation and development of the socialist productive forces, contributes to the national unity, ethnic unity and social progress, makes for the pursuit of truth, goodness, beauty, and the resistance to false, evil and ugliness, and promotion of the ideological and moral integrity, and that is to the benefit of the performance of civil rights and obligations, with honest labor for a better life", should be encouraged and supported. Therefore the ideological and political education should not be limited to the old frames, but should make the past serve the present and the foreign serve the Chinese purpose, comprehensively melt the wisdom that is old and new, foreign and domestic so as to achieve innovation.

The liberation of the concept and thought of ideological and political education and the diversity and innovation of 
the content does not mean the pluralism of guiding thought of ideological and political education. On the contrary, ideological and political education is always under the guidance of Marxist thought, which is under the guidance of the socialist ideology. The guiding ideology of ideological and political education can only be unitary, instead of multiple. Only in this way, can it be ensured that the great building of socialist construction stands firm. Guiding ideology is the basic principle, which determines the nature of education. The concept and thinking of education are pluralistic and flexible, which reflects the changing direction of the times.

\section{B. Unclear Object Relationship}

The unclear object relationship does not mean that the subject of education is not clear about the object of education, but that the subject and the object of education are not at the same level and do not constitute the equal and dialogical relationship. The goal of ideological and political education lies in human, which means the students. But "traditional ideological and political education believes that teachers are the subject and students are the object. Therefore, teachers' subjectivity and authority are always emphasized in the teaching process, while students are passive in learning the knowledge and theories taught by teachers." [3] Therefore, human-oriented purpose of the ideological and political education does not stand out.

The key factor that leads to the unclear relationship between ideological and political education lies in the fact that educators don't understand and follow up the close relationship between the current situation of the development of ideological and political education of college students and the development of the times and don't innovate in the process of teaching. The traditional "cramming" teaching method pays attention to the teacher's subject status and authority, but ignores or pays less attention to the student's subject status and active learning style. Only by changing the closed and single authoritative teaching mode into a two-way interactive, exploratory and consultative teaching mode can the current unclear relationship between teachers and students be completely changed so as to stimulate students' active learning spirit and teachers' enthusiasm for teaching. It is conducive to both teachers' teaching and students' learning that both sides constitute the subject status of equal consultation and build an interactive learning platform the teaching law of virtuous circle can easily help to promote the formation and exploration of higher level teaching mode. Only in this way can the education truly conform to the modern education concept and constantly promote the expansion and deepening of ideological and political education in colleges and universities.

As the world enters the stage of diversified development, ideological and political education should timely adjust the internal element composition of education, so as to meet the growing rule of education and deepen the response to the complex world and diversified thoughts. This requires teachers to give up their dominant position and authority and pay attention to students in a more humane teaching mode. Students should be allowed to participate in education activities as the main body, and it does not mean to abandon the guidance and guidance of teachers, but to adjust their bilateral relations and treat them equally. Teachers and students should stand on the same platform, look at both sides from the perspective of humanity, so that students can be put in a free individual with their own thinking attributes and value attribution. In this way teachers and students can interact with each other in the teaching process. Only with such a teaching relationship model can equal consultation be truly achieved. However, due to the core and authoritative role of teachers and the habitual conventional thinking in the traditional teaching process, the subject relationship mode of ideological and political education cannot be smoothly implemented. The future of ideological and political education still has a long way to go.

\section{Lack of Institutional Guarantee}

The current ideological and political education systems cannot be routinized or standardized, or there are systems that cannot be well implemented, with inadequate supervision and low efficiency. Of course, the bottleneck in the implementation of the system for universities should also be noticed. The power distribution of education management system will also affect the talent training mode of colleges and universities. Inside the universities, there are conflicts between the scientific research system and the teaching system as well as structural imbalance. For example, the leading power of talent cultivation in colleges and universities is in the secondary colleges, and each college carries out practical operation according to the overall planning and arrangement of the office of academic affairs of the school. However, the advantages of the office of academic affairs in student affairs management of colleges and universities cannot reduce the disadvantages in student cultivation, and the latter is the specialty of teachers' committees of various schools and departments. Therefore, the office of academic affairs should grasp the degree of loose and tight, wide and professional management, in order to give full play to the cooperative cultivation mechanism and talent innovation system.

The implementation of the system is the guarantee of sound organization and the touchstone of the effect of ideological and political education. Without the system, there would be no normal and healthy development of the work of ideological and political education in colleges and universities. Colleges and universities need to strengthen the leadership system, work system and incentive mechanism, integrate all resources, and jointly promote the ideological and political education work of colleges and universities to move in the direction of high level, strong organization and outstanding effect.

\section{THE BREAKTHROUGH OF IDEOLOGICAL AND POLITICAL EDUCATION IN COLLEGES AND UNIVERSITIES}

In view of the disadvantages of education in ideology and politics in universities, and colleges discussed above, it is necessary to break through the predicament from the following aspects: 


\section{A. Concept Innovation}

1) Ideological and political education in universities and colleges should be theoretically guided by socialist core values: The core socialist values are the creative transformation and innovative development of the excellent traditional Chinese culture, which are highly realistic and instructive. They have been constantly condensed and summarized in line with the national conditions of China's leading values in the practice of socialism. To uphold the core socialist values, the key is to adhere to the living Marxist theory and guiding ideology. Educators must truly understand the fundamental position, viewpoint and theory of Marxism, truly understand the critical spirit and revolutionary spirit of the unity of Marxism's science and humanity, and truly grasp the soul of Marxism. History and practice at home and abroad have proved that the security of ideology is related to the stability of a country and the prosperity and survival of a nation. Therefore, at no time and under no circumstances should the core socialist values or the ideological guiding role of Marxism be abandoned. Educators should integrate the thought and soul of Marxism into their daily work and thoughts and constantly promote the Sinicization, modernization and popularization of Marxist theories.

2) Ideological and political education in universities and colleges should adhere to the cultivation standard of "top-notch innovative talents": The term "top-notch innovative talents" refers to high-quality, competent and high-level outstanding talents with innovative spirit and consciousness in various fields, especially in the fields of science, technology and management, who have made great contributions and exerted great influence on the progress and development of the country, nation and the world at large. [4] It can be seen that innovation is the key point in the cultivation mode of top-notch innovative talents. The purpose is to cultivate outstanding talents with comprehensive quality as an essential condition. This kind of talented person is very different with the traditional talented person in terms of the knowledge structure, the practical ability and the sentiment sense of responsibility. Top innovative talents must have a wide range of knowledge, complex comprehensive ability and a high sense of responsibility for the rimes. And all of this needs to revolve around the theme of innovation. Both the talents with high IQ and those with high Eq need to emancipate their minds and activate their thinking. So innovation must be made to cultivate talents that are in line with the needs of the times, can cope with the extreme test from harsh conditions under the modern background of high intensity and complexity. However, in order to achieve theoretical innovation in the new era of ideological and political education, it is necessary to cultivate high-end and top-notch talents of such a compound type.

3) Ideological and political education in colleges and universities should be problem-oriented: The realistic pertinence of education in ideology and politics must start from China's realities. Only by finding the holes can educators make a breakthrough with high efficiency. Liu Yandong stressed that education should "adhere to the problem orientation and promote theoretical innovation". The research of theory of ideological and political education should focus on the "new" problem, the "major" problem, the "actual" problem, and also emphasize the "old" problem. Ideological and political education should constantly respond to the call of the times and carry out work in a scientific and orderly manner in accordance with the ideas of raising, analyzing and solving problems. "To promote the innovative development of ideological and political education requires arousing the awareness of the problems in this subject more widely and to aim at the leading edge issues, and focus on the reality. It requires discovering, focusing on and solving major theoretical and practical problems in the rich and vivid practice of ideological and political education. That means to set goals and solve problems one by one unswervingly and persistently." [5]

\section{B. Innovation of Object Relationship}

The 18th national congress of the communist party of China has clearly required that the education of ideology and politics should pay attention to humanistic care and psychological counseling to cultivate the social mentality of self-esteem, self-confidence, rationality, peace and positive progress. The core socialist values have also established the ideas of "freedom" and "equality". Therefore, the rethink of the relationship between teaching and learning in education work and of education objects has become an inevitable trend. From the disadvantages of object relationship discussed above, the defects of the current ideological and political education are easy to see. Here are things that need to be made clear:

1) Establishing the subject consciousness of the object: The object thinking of modern ideological and political education requires that both sides should be put on a platform where the educator and educatee can be the subject to each other, which is somewhat a reflection and an embodiment of "intersubjectivity". The philosophy of "intersubjectivity" was first expressed in the phenomenology of the western philosopher Husserl, while when it comes to Heidegger, the philosophy of subjectivity became the ontology of existence. Intersubjectivity, as an ontological stipulation, is the transcendence of the reality of opposites between subject and object. In philosophy, Intersubjectivity refers to the ontological stipulation that existence is not the existence of the object or the isolated existence of the subject, but the existence of intersubjectivity, which includes not only the relationship between people but also the relationship between man and nature. Therefore, in the relationship between teachers and students, a subjective consciousness should be hold, which is an intersubjective relationship. And this is the 
precondition of the equal dialogue between the educator and the educatee.

2) Clarifying the principle of participation in teaching: The main role of the object shows that both sides of education are participants in the teaching process. This represents that it's not that one side decides the other, but that both sides participate and improve together. At present, higher education has clearly put forward the idea of "students as the main body of teaching". It has developed into "cultivating through teaching" from "teaching and cultivating", which is the foundation of the reform of the education teaching reform in higher education institutions.

Tao Xingzhi, a famous educator, once said with his worry about the development of higher education: what the students do is to learn to deal with exams and what the teachers do is to teach people to handle exams. Therefore it seems that a must to teach what an exam requires while it does not seem necessary to teach anything that is not required by the exam. "Teaching is not just about teaching 'books'; it's more about teachers guiding and helping students to learn knowledge and the way of learning. Since students have the subjective initiative, teachers can only play the leading and main role in the interaction between each other, to truly achieve mutual beneficial teaching and learning. "[6] Teaching and learning are a unified process, which cannot be separated distinctively. The unity should be based on mutual participation and interaction.

3) Advocating the spirit of equal dialogue: Whitehead's "philosophy of process" is the clear embodiment of the spirit of dialogue. In his view, the ancient education was designed to seek wisdom, while the modern education was reduced to teaching specific subjects. "The degeneration of the pursuit from sacred wisdom of the ancient people to modern people's acquisition of book knowledge on various subjects marks the failure of education in a long time."[7] Such understanding comes from the instrumental purpose of modern entity education, which ignores students' status as subject and their active creativity. He opposes the indoctrination of traditional education, and advocates the vitality and vitality of students' learning, and focuses on guiding students' self-development.

The establishment of dialogue relations requires equal dialogue between the two sides, with the establishment of subject consciousness as the premise. On this basis, interactive participation in the teaching process should be brought into play to actively construct a reasonable and orderly ecological dialogue environment. Here, Bakhtin's "theory of dialogue" and Habermas's "communicative rationality" have important implications for the equal dialogue between the two sides. The former pays attention to the chorus and independent spirit of all roles in the novel text, while the latter pays attention to the dialogue spirit of different speakers. Both pay attention to the interlocutor and the dialogue spirit. It is absolutely necessary and feasible to extend these theories to the understanding of ideological and political education in colleges and universities.

\section{Institutional Innovation}

Institutional innovation is the guarantee. College students' ideological and political education system should be standardized and put into daily practice, and daily incentive and assessment systems should also be established to achieve the balance of constraints and management, selfdiscipline and heteronomy. This is embodied in the following aspects in particular:

1) Strong leadership system: The CPC central committee stressed in "the implementation opinions on adhering to and improving the principal responsibility system under the leadership of the party committee of ordinary colleges and universities (October 2014)": The party committee of the institution of higher learning is the core of leadership of the university. It performs various functions and duties stipulated in the party constitution, grasps the development direction of the university, decides major issues of the university, supervises the implementation of major resolutions and supports the principal independently and responsibly exercising his/her functions and powers in accordance with the law, so as to ensure that all tasks centered on talent training are completed. As the legal representative of the university, the principal carries out the education policy of the party under the leadership of the university party committee, organizes the implementation of relevant resolutions of the university party committee, exercises various functions and powers stipulated in the higher education law, and is fully responsible for teaching, scientific research and administrative management. Colleges and universities should "establish and improve the leadership system and working mechanism of the unified leadership of the party committee, the joint efforts of the party and government, the combination of full-time and part-time teams, the close cooperation of the whole university, and students' selfeducation".[8] The establishment of education leadership mechanism of ideological and political education in colleges and universities is the embodiment of strengthening the modern spirit of contract. Of course, leaders should also improve their own quality in time to meet the requirements of modern management level.

2) Standardized working system: The working mechanism of the ideological and political education of colleges and universities should be standardized and put into daily practice. The system of instructor communication and training should be established so that the team building level can be improved. A student assistance system should also be established to help students with difficulties solve practical difficulties in daily life and study. And a class tutorial system should also be put up so that the mode emphasizing teaching and management more than instruction can be transformed. The instruction should be put at a dominant position in the mode featuring individualization and heartwarming relationship. Specifically, students of each grade should be divided into several classes, each class divided 
into several study groups, and one or two tutors should be responsible for each group and provide guidance for student's study, life and so on. This is just what "Be close to one's teachers, take pleasure in making friends and be faithful to what one has learned (from an article of 'The Book of Rites')" indicates.

Of course, in addition to counselors and student mentors, head teachers and assistant head teachers also play a practical role in ideological and political education. "Mentors can guide students according to their own professional characteristics, and provide students with a path that is most conducive to their development considering different interests and hobbies of each student. However, counselors who play a key role always accompany these students in the process of college life and study. They are the leading line connecting the head teacher, assistant of the head teacher and the mentor. They well manage student work globally, integrally and systematically, and play an irreplaceable role in training students to grow into talents. In each link of students' growth, counselors, head teachers, assistants of head teachers and mentors all have laid a solid foundation for their success in different jobs." [9]

3) Effective incentive mechanism: Effective incentive mechanism can play a greater education effect. Standardized and reasonable awards and incentive measures within a certain range can stimulate the initiative of students and teachers and thus make the effect of ideological and political education more obvious. Such mechanism is an effective test stone of Teacher's work achievement, and student's study result. The incentive mechanism of college ideological and political education can be divided into two forms: target incentive and defense incentive.

Target incentive is to carry out ideological and political education activities around a certain goal. Goals have a guiding role, so ideological and political workers can use the setting of goals to stimulate people's interest, arouse people's motivation, adjust people's behavior, and inspire people to strive for goals. Of course, the goal of Target incentive should be clear, operable and take into account the actual completion.

Defense incentive is a summary exchange activity carried out by examining the actual education results of ideological and political activities. The ways and forms of defense incentive are diversified, which can either be personalized defense, examination or reflection of practical experience.

Target incentive and defense incentive are two kinds of incentive measures to carry out the education activity of ideological and political activities in colleges and universities. Both of them can be implemented in the form of material reward and spiritual encouragement. The purpose is to stimulate the morale, encourage the spirit and give full play to the maximum effect and level of ideological and political education in colleges and universities.

\section{CONCLUSION}

Ideological and political education in universities must keep pace with The Times. The concepts should be constantly renewed with the development of the times, and the object relationship should be clarified, thus the ideological and political education of colleges and universities can be promoted with effective incentive mechanism. Of course, China has made some achievements in the mode of education in ideological and political education innovation, but the influence is far from universal. On the one hand, it shows the painstaking road of exploring any innovation of mode and concept; on the other hand, it shows the insufficient innovation intensity and defects and specific implementation in ideological and political education in colleges and universities. The traditional psychological habits, resource constraints in methods and means, and incomplete implementation of the assessment mechanism are all examples.

In any case, the alarm bell of education reform of higher education is awakening. The ideological and political education of colleges and universities, which is at the forefront of the growth of college students into talents, should undertake its due responsibilities and play its role in the stimulation of reform. The purpose of education, as the great Russian writer Gorky called: "all should be the concern of the people, all should be done for the people, only people!'’[10]

\section{REFERENCES}

[1] Feng Gang. Cultivation of top-notch innovative talents and thoughts on the enhancement of graduate students' ideological political education [J]. Studies on ideological education, 2009 (10): 12. (in Chinese)

[2] Central Committee of the Communist Party of China. Decision of the central committee of the communist party of China on several major issues concerning strengthening the construction of socialist spiritual civilization [Z]. 1996-10. (in Chinese)

[3] Ji Meiling. Research on education innovation of ideological and political science in universities under the cultivation mode of topranking innovative talents [D]. Master thesis of Southwest Petroleum University, 2012:22. (in Chinese)

[4] Hao Keming. Training top innovative talents and higher education reform [J]. China Higher Education Research, 2003 (11): 7-12. (in Chinese)

[5] Feng Gang. Deepening theoretical research and practical innovation of ideological and political education and promote the prosperity and development of the discipline of ideological and political education [J]. China Higher Education Research, 2015 (2): 16. (in Chinese)

[6] Liu Jia et al. Research and thoughts on the construction of studentcentered "education and learning process" $[\mathrm{J}]$. Research on higher education in China, 2012 (6): 108. (in Chinese)

[7] Whitehead. The purpose of education [M]. Translated by Xu Ruzhou. Shanghai: SDX Joint Publishing Company, 2002:52. (in Chinese)

[8] Issued by the general office of the CPC Central Committee. Opinions of the CPC Central Committee and the State Council on further strengthening and improving moral education of college students [Z]. 2004-02-26. (in Chinese)

[9] Qin Pengju. Research on the management mode of "class guidance" system for college students [J]. Inheritance. 2010(10): 123.(in Chinese)

[10] [Russia] Gorky. The Lower Depths [M]. Fang Xin translated. Collection of 60 classic dramas for Students of The Central Academy of Drama, 2014:684. (in Chinese) 